\title{
Adressing the Sustainable Agricultural Agenda: Gac Fruit Benefit in Qur'an and Value Chain Perspective
}

\author{
Hasrul Bin Hashom ${ }^{4}$ \\ ${ }^{1}$ Fakulti Perniagaan \& Sains Pengurusan, Kolej Universiti Islam Perlis \\ ${ }^{2}$ Department of Agrotechnology, Universiti Malaysia Terengganu \\ ${ }^{3}$ Fakulti AL Quran \& Sunnah, Kolej Universiti Islam Perlis \\ ${ }^{4}$ Pusat Bahasa \& Pengajian Umum, Kolej Universiti Islam Perlis \\ *Corresponding author. Email: shabudin@kuips.edu.my
}

Ahmad Shabudin Ariffin 1,*, Ramisah Mohd. Shah², Khalilullah Amin Ahmad ${ }^{3}$, and

\begin{abstract}
Gac fruit is one of the exceptional varieties of fruits that contain numerous secrets and wonders; which according the text of Qur'an, the benefits of fruits in paradis frequently discussed and as natural resource, medical and health. However, since prior studies have solely concentrated on the content and nutrients of Gac fruit, the value chain ecosystem for this valuable product has not been explored through research. Therefore, this concept paper will literately focus on the nutritional position of this fruit according to the text in the Quran as well as the exploring the value chain that can strengthen the viability of the product. Methodology used to provide sufficient information on Gac fruit are the Qur'anic literature and value chain inter-sectoral upgrading model literature review. The findings of the study is expected to provide a list of Gac fruit's benefit according to Quran and products value chain as part of a large -scale source of food security and sustainability, as well as to reinforce the national aim in the Sustainable Development Goal led by the Ministry of Agriculture and Food Industry (MAFI).
\end{abstract}

Keywords: Gac fruit, Al-Quran, value-chain, inter-sectoral upgrading model

\section{INTRODUCTION}

Agriculture, in Malaysia, is an important field. This sector has been the backbone of the Malaysian economy for many years, delivering agricultural products for domestic consumption, as the foreign exchange earner. Additionally, agriculture contributes to the national Gross Domestic Products (GDP).Production efficiency in today's global economy is not only dependent on business competitiveness, but also product quality, safety, pricing as well as

biodiversity preservation. Modern technologies and updated ways of product management will able to enhance the values of commodities. One must admit that agriculture in the modern era is not only about farmingit's a business in the agriculture industry opened to quick changes and threat. It provides the people with significant employment, particularly from the rural areas. This sector employs more than 1.6 million workers, or $10.9 \%$ of total jobs, contributed more than $23 \%$ of tota export earnings, and contributes around 7.2\% to Malaysia's GDP "[42]”.

This inevitable phenomenon is due to several factors such as the rapid growth of the world economy, market liberalization, rapid urbanization, and rapid increase in demand for food. In line with the economic growth, there are staggered outbound movements concerning the foodcrop output to a production system that is more oriented to market diversity or commercialized production system. Commercialization of the agriculture industry has been undoubtedly being supported strongly by the advent of strong supply chain implementation. In return, the whole chain will be affected by value introduce in inter-sectoral of each flow and indirectly influence the product value-driven to customers. To understand the impact of inter-sectoral upgrading on the agricultural product especially in Malaysia, this concept paper will do a review on Gac Fruit and discuss on the most relevant value-chain structure as it will consider as new finding on transferred innovation to the customer are and also changing in tandem with the commercialization of the agriculture industry - from simple production to value trading.

\section{THE IMPORTANT OF GAC PLANT AND ITS BENEFIT IN AL-QURAN}

Perry and Metzger (1980) believes, as a native and indigenous plant, Gacfruit (Momordica cochinchinensis 
Spreng) has grown through hout Asia (China, Japan, and Taiwan), Malesia (Philippines, Malaysia, and Indonesia), Indochina (Thailand, Cambodia, Laos, Vietnam, Myanmar),the Indian subcontinent (Bangladesh and India in the specific areas such as Assam, Nagaland, Tamil Nadu, Uttar Pradesh, and West Bengal), Papuasia (Papua New Guinea), and also Northeastern Australia (Queensland) [21,49]. The plant categorize as vigorously perennial vines where males and females flower on separate plants.

Based on Nhung, et. al (2010), it has been utilized traditionally as a food and local medicine source in Southeast Asia, Gac fruit is considered to be good for health as many components of Gac such as its seeds, oil, and root are used as traditional cure. Historically, Gac plant was already established as medicine source especially in China and Vietnam for centuries.

As a traditional medicine, Crisp (2012) explained that the used of Gac seed used for treating a range of issues such as wounds, bruises, swelling, diarrhea and dysentery, liver and spleen disorders, haemorrhoids, and pus. These functional components have significant health benefits for humans and previous research scientifically prove that Gac fruit rich in nutrients, containing very high

Table 1. Analysis of Types of Fruits, Quranic Propositions and Vitamin Conten

\begin{tabular}{|c|c|c|}
\hline $\begin{array}{l}\text { Types of } \\
\text { fruits }\end{array}$ & $\begin{array}{c}\text { Verses of the } \\
\text { Qur'an }\end{array}$ & Vitamin Content \\
\hline Bananas & $\begin{array}{l}\text { Al-Waqi'ah (56): } \\
2729\end{array}$ & $\begin{array}{l}\text { Fiber, potassium, vitamin A, } \\
\text { vitamin K, vitamin C and iron }\end{array}$ \\
\hline Figs & Al-Tin (95): 1 & Vitamin B6, vitamin C, \\
\hline Dates & $\begin{array}{l}\text { Maryam (19): } 24- \\
26\end{array}$ & $\begin{array}{l}\text { Iron, protein, phosphorus, } \\
\text { vitamin A, vitamin C, vitamin } \\
\text { D, vitamin E and vitamin K }\end{array}$ \\
\hline Olives & $\begin{array}{l}\text { Al-Nahl (16): } 11 \mathrm{Al}- \\
\text { Tin }\end{array}$ & $\begin{array}{l}\text { Fiber, potassium, vitamin A, } \\
\text { vitamin K, vitamin C and } \\
\text { iron }\end{array}$ \\
\hline Grapes & Al-Nahl (16): 11 & $\begin{array}{l}\text { Vitamin A, vitamin C, } \\
\text { vitamin B6, } \\
\text { potassium,calcium, iron, } \\
\text { phosphorus }\end{array}$ \\
\hline $\begin{array}{l}\text { Pomegra } \\
\text { nates }\end{array}$ & Al-An'am (6): 141 & $\begin{array}{l}\text { Nitric acid, fructose, } \\
\text { vitamin A, vitamin C, } \\
\text { magnesium, iron and } \\
\text { potassiumc }\end{array}$ \\
\hline
\end{tabular}

levels of including carotenoids, $\alpha$-tocopherol, omega-3 fatty acids, polyphenol compounds, and flavonoids $[2,3,27]$ with high phytonutrient value in all its fractions (i.e. aril, seeds, pulp and, peel) (n.d).
Generally Parks, Nguyen, Gale, and Murray, (2013) stated that gac fruit consider as "super- fruit" or "heaven's fruit"[50], studies on pharmacological activities also has demonstrated throughout the in vivo and in vitro over Gac seeds, (which also support by Do.T.V.T et. al, 2019).

Up till now, Gac fruit is only planted on a small scale as commercial crop in Vietnam and Thailand. The ripe fruit is usually picked in outdoor growing systems from August through February. The greenhouse growth systems need to be extended to meet Gac 's demands for fruit and provide stability all year round and the effort was widely plan by various countries whose also aware of the benefits of this plant. This including Australia which serious experimen over the Gac plant sample and presented through food. Review International Journal with topic so-called "Gac Fruit: Nutrient and Phytochemical Composition, and Options for Processing, with used scientific method in explaining the versatility of the fruit including the processing options outlined for fruit aril, seeds, pulp, and skin into powders and/or encapsulated oilnproducts with end products such as pasteurized juice and milk beverages, glutinous rice, yogurt, pasta, and sauces. Table 2.0 clearly listed the respected country which advance in manufactured Gac fruit products with variety of parts and uses;Fruits are a gift of the Almighty God. The diversity of benefits and nutrient content proves its supreme power [45]. Discussions about the fruits of paradise have been recorded in the Qur'an, and research is still ongoing. The scholarly study has been described by scholars and it is discussed in various angles. Examples of references book are al-Nabat (1974), al-Thimar wa al-A'syab al-Waridah fi al-Qur'an alKarim wa al-Sunnah al-Nabawiyyah (2006) and Asrar al-Nabat (2009) (Muhammad Ali, 2012; al-Hadi; Qadah, 2009; Muhammad, 2006). The results of research by the researcher found that there are verses of the Qur'an that are recorded containing the words of fruits such as figs (al-Tin), olives (alZaitun), bananas (Talh), grapes ('Inab), pomegranates (alRumman) and dates (al-Nakhl) [6].

The vitamin content is described by scientists who specialize in the field (Nur Khasanah, 2011). This can be described in Table 1.

This commercialize factors was also attracted our local researchers and scientist to explore more on the important of Gac plant for the benefits of our economy. This was clearly showed through our local scientist called Gac (Moordica Cochinchinensis Spreng.) Fruit and Its Potentiality and Superiority In - Health

Benefits, reveals more potential benefits of Gac plant including DNA Protective activity, Anti-cancer activity, Anti-microbial activity, Anti-ulcer activity, Antiinflammatory activity, and many more which not discover scientifically before. The numbers of research not just justified the important of Gac fruit/plants but also 
Table 2. Production Of Gac Fruit Products

\begin{tabular}{|c|c|c|}
\hline $\begin{array}{l}\text { Manufacturers/ } \\
\text { Trading companies }\end{array}$ & Country & GacProducts \\
\hline $\begin{array}{l}\text { MagnaGac } \\
\text { Phusirath } \\
\text { Company Limited }\end{array}$ & Thailand & $\begin{array}{l}\text { Extract Powder } \\
\text { Juice Blend } \\
\text { Skin Balm }\end{array}$ \\
\hline $\begin{array}{l}\text { D2 Holding } \\
\text { Company Limited } \\
\text { P.O.P. Siam Golden } \\
\text { Fruit Limited } \\
\text { Partnership } \\
\text { Lycopenelover Co,. } \\
\text { Ltd. }\end{array}$ & & Soap \\
\hline $\begin{array}{l}\text { Xian Aladdin } \\
\text { Biological echnology } \\
\text { Co., Ltd. }\end{array}$ & China & Gac Fruit Enzyme \\
\hline $\begin{array}{l}\text { Xi'an Chen Lang } \\
\text { Biological } \\
\text { Technology Co., } \\
\text { Ltd. } \\
\text { Hunan Greenland } \\
\text { Plant Resource } \\
\text { Development Co., } \\
\text { Ltd. }\end{array}$ & China & $\begin{array}{l}\text { Drink } \\
\text { Extract Powder } \\
\text { Juice }\end{array}$ \\
\hline $\begin{array}{l}\text { VNPOFood } \\
\text { Hanfimex } \\
\text { Moocos Vietnam } \\
\text { Co., Ltd. Rita Food } \\
\text { \& Drink Co., Ltd. } \\
\text { Sunrise Viet Nam } \\
\text { Technology Joint } \\
\text { Stock Company } \\
\text { Viet Nam Herbal } \\
\text { Oil Joint Stock } \\
\text { Company }\end{array}$ & Vietnam & $\begin{array}{l}\text { Puree } \\
\text { Gac Concentrate } \\
\text { Frozen Aril } \\
\text { Juice EXtract } \\
\text { Powder Gac } \\
\text { Oil } \\
\text { Gac Fruit Jam Gac } \\
\text { Oil Capsules Tea } \\
\text { BiscuitsSoap Skin } \\
\text { Balm Gac seed } \\
\text { alcohol }\end{array}$ \\
\hline
\end{tabular}

the seriousness of industry players and government to tap on the economy opportunity provide by the Gac plant product.

The Qur'an contains 6236 verses in 114 chapters. The Qur'an has proven that this power serves as the greatest miracle to the Prophet Muhammad SAW. The various greatest secrets and miracles in the Qur'an have been the focus and relevance of all time. All the rules and methodologies that are enshrined become a source of lifestyle for believers until the Day of Judgement [57].

The fruit is rich in various sources of active ingredients such as phytochemical rich sources especially carotenoids and contains high antioxidant capacity for enzymatic treatment and eyelid parts [4], 31]. The nutrient content found in this fruit is vitamin $\mathrm{A}$, antioxidants, beta-carotene, lycopene and zeaxanthin [32].

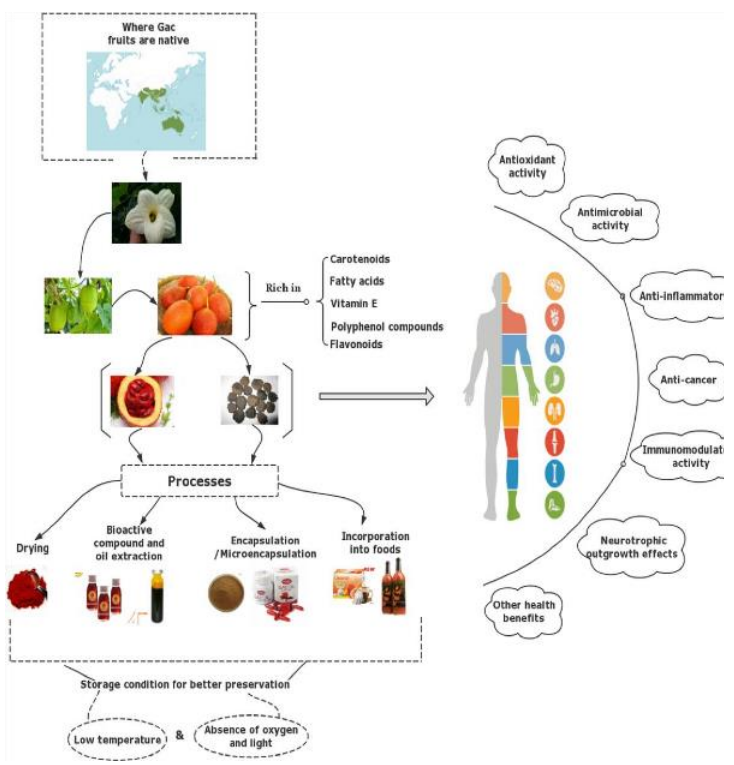

Figure 1. Phytochemical Composition, Options For Processing,and Potential Health Benefits Of Gac Fruit

Based on the researcher's findings, the gac fruit which is said to be the fruit from heaven does not mean that the fruit is in heaven or descended from heaven. It is so as a sign of respect and the privilege of the benefits contained in it.

Moreover, this fruit is not mentioned in the Qur'an as the fruit of heaven, in fact this fruit is referred to as micronutrition [40]. However, the nutrient content contained in this fruit is almost equal to the nutrient content found in the six types of fruits recorded in the Qur'an. In fact, the benefits of this fruit are equal in terms of benefits and health of the human body. This proves the sign of the greatness and power of Allah SWT who makes various types of fruits. However, every good, halal and pure food is highly recommended in Islam. In the treasury of the 
Qur'an, the recommendation to choose food is clearly quoted several times in it either in terms of concepts, criteria and examples related to "Halalan Toyyiban" (halal and good) [20]. Allah SWT says in Qur'an which means:

"O mankind, eat from whatever is on earth [that is] lawful and good and do not follow the footsteps of Satan. Indeed, he is to you a clear enemy." (QS. Al-Baqarah [2]: 168).

In another surah, Allah SWT also says in Qur'an which means:

"So eat (O you who believe) of what Allah has bestowed on you of lawful and good things, and be grateful for the favors of Allah, if it is true that you worship Him alone." (QS. Al-Nahl [16]: 114)

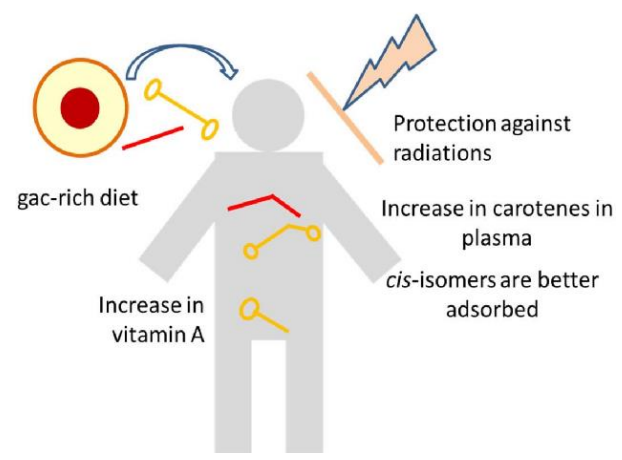

Figure 2: Nutritional studies on Gac-based diet

Source: Phan-Thi, H., \& Waché, Y., (2019).

It is also mentioned in Qur'an which means:

"And eat of what Allah has provided for you [which is] lawful and good. And fear Allah, in whom you are believers." (QS. Al-Maidah [5]: 88).

It is clear from these verses that the aspect of nutrition is emphasized by the Qur'an. This is because the implications are enormous whether in terms of behavior, psychology, or even Islamic jurisprudence (fiqh). Illegal food can give birth to savage behavior, dayus attitudes [19]".

\section{PRODUCT VALUE-CHAIN: THE INTERSECTORAL UPGRADING MODEL}

This idea of MODEL is inspired by Tran Thi Dien \& Hoang Anh Dao (2018) in their article of "Developing Orange Fruit Value Chain In Tuyen Quang, Vietnam" and Michael Vysin (2017) thesis paper entitle "The Role Of Development Cooperation For Upgrading In Uganda's Organic Fruit Value Chain". Both studies was clearly frame out the good practices of value chain management toward agricultural product that would able to increase the value-driven over the product. Ponte (2008) defined inter-sectoral upgrading as moving into new productive activities (which related industries), using knowledge gained through the development of another product or a specialized service, whereas the industries prefer to migrate to more competitive value chains. Otherwise, stated by Mitchell et. al, (2009), there would be no reason to go with inter-sectoral upgrading even they aware of barriers to enter other value chains are challenging and very high to overcome especially vulnerable and small players. Humphrey \&Alemán (2010) propose four categories in a classification of interventions;

\subsection{Improving knowledge and resource flows}

Communication, and particularly knowledge transfer, identified as a major role in value chains. It is crucial for suppliers to know exactly what the customer needs from them. It is also particularly difficult when they are exporting to overseas markets. This condition may also lead to missed opportunities, as customers does not know what their manufacturer will deliver. Moreover, not just the flow of knowledge is important, resource flow also crucial. Providing suppliers with materials, technological support etc. can create a positive effect on the supply chain and also provide opportunities for the entrants.

\subsection{Improving linkages}

Trust plays a major role, therefore improving linkages is closely related to improving the flow of knowledge and resources. Increasing complexity in business relationships and economies' informal character can cause high transaction costs, which have a negative effect on value chains. Establishing institutions to manage risks and develop trusting relationships will help foster effective business operations.

\subsection{Developing new or alternative links in the chain}

New linkages can help to solve problems such as the scarcity of raw materials while alternative linkages can make processes more productive. Contrary to targeting current value chains linkages, intervention often aim to build new or alternative linkages, respectively.

\subsection{Working on the weakest link}

The rationale for intervention is obviously to set every linkage of value chains are functioning and successful in performance. At the bottom of the chain, where linkages are weak, actors in developed countries continue to be incorporated into value chains. Therefore, 
it is a part where development cooperation initiatives are launched.

Development of Gac plant value chain for sustainable agriculture will bring great economic values for the

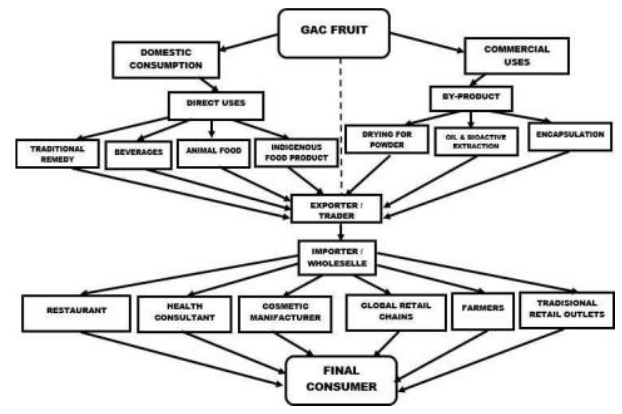

Figure 3 Gac-Fruit Value Chain Inter-Sectoral Upgrading Model Adaptation: Inspired by Tran Thi Dien \& Hoang Anh Dao (2018)

nation. Other than supply for domestic consumption and by-products to consumers, effectively use economic resources, protect the environment and preserve biodiversity, it is also bringing high and stable income for local people, help reduce poverty, provide jobs for rural workers in various sectors such as restaurants, health consultant, cosmetic manufacturers, farmers, including local and global retailers.Major actors in the Gac plants value chain for domestic consumption and commercial purposes include orchard owners, fruit pickers, local fruit marketers and exporters, product processing factories, industries that engage in the utilization of direct uses and by-products for the production of traditional and commercialize products. This value chain retaliation started with farm inputs such as nurseries, fertilizers and agro chemicals, are at the bottom of the Gac plant value chain with the end points in large processing involve export and import activities by traders and wholesalers for domestic and global market. Based on the information above and the objective of the study to develop productvalue chain for sustainable agriculture and propose solution for Gac plant production and marketing value chain, Figure 3 illustrate The Gac. Fruit Value Chain Inter-Sectoral Upgrading Model as follow;

From production to delivery of a product and end-up to market with participants involved in the sequence of steps and process is called a value chain. To improve productivity and the value added of activities, value chains are organized linkages between groups of producers, traders, processors, and service providers. By joining together, value chain between participant's increase competitiveness and able to maintain through innovation. The limitations of each single participant in the chain are overcome by governance rules and establishing cooperation with aimed for producing higher value. Being able to reduce the costs of production and business; increase revenues; increase bargaining power; improve access to technology, information, and capital are the main objective to stakeholders from being part of an effective value chain.

.By doing so, innovate production and marketing processes will surely gain higher value and provide higher quality to customers, promising sustainable agriculture, improve the overall natural sustainability of the entire chain and optimizing links between actors.

\section{CONCLUSION}

Development of Gac plants industry in Malaysia will surely provide growers and consumers with a new agriproduct which also has marketability as a 'super fruit' with multi uses. Furthermore, the Gac plants industry would be position as supply high quality product and increasing market projected to be worth for the economy. Therefore, other than science-based information on fruit production and processing that already widely operated for years, the idea of establishing and developing the industry also requires an advisory component that could promote linkages among future stakeholders in the industry by generate product value chain to promote value driven among stakeholders. Thus, this study presented the Product Value Chain Inter-Sectoral Upgrading as review on Gac Fruit Value Driven.

\section{REFERENCES}

[1] Aamir, M., \& Jittanit, W. (2017). Ohmic heating treatment for Gac aril oil extraction: Effects on extraction efficiency, physical properties and some bioactive compounds. Innovative Food Science \& Emerging Technologies, 41, 224-234.

[2] Abdulqader, A., Ali, F., Ismail, A., \& Esa, N. (2018). Gac (Momordica cochinchinensis Spreng.)

[3] fruit and its potentiality and superiority in-health benefits. Journal of Contemporary Medical Sciences, 4(4), 179-186.

[4] Abdulqader, A., Ali, F., Ismail, A., \& Esa, N. M. (2018). Gac fruit extracts ameliorate proliferation and modulate angiogenic markers of human retinal pigment epithelial cells under high glucose conditions. Asian Pacific Journal of Tropical Biomedicine, 8(12), 571-579.

[5] Abdulqader, A., Ali, F., Ismail, A., Esa, N. (2019). Antioxidant compounds and capacities of Gac (Momordica cochinchinensis Spreng) fruits. Asian Pacific Journal of Tropical Biomedicine 9(4), 158-167.

[6] Akhter, F., Al-Razi, M., Chowdhury, F. B., Ara, N., Rahman, M., \& Rahmatullah, M. (2014). Oral glucose tolerance and analgesic activity 
evaluation with methanolic extract of fruits of Momordica cochinchinensis. Journal of Chemical and Pharmaceutical Research, 6(9), 322- 327.

[7] al-Fairuz, A. M. D.M. (2005). Qamus al-Muhit. Beirut: Dar al-Jil. al-Hadi, A. M. Fal. (t.th.).

[8] 'Alam al-Nabat fi al-Quran al-Karim. Qaherah: Dar al-Fikr al-'Arabi.

[9] Aoki, H., Kieu, N. T. M., Kuze, N., Tomisaka, K., \& Chuyen, N. V. (2002). Carotenoid pigments in GAC fruit (Momordica cochinchinensis SPRENG). Bioscience, Biotechnology, and Biochemistry, 66(11), 2479-2482.

[10] Bernstein, P. S., Li, B., Vachali, P. P., Gorusupudi, A., Shyam, R., Henriksen, B. S., \& Nolan, J. M. (2016). Lutein, zeaxanthin, and meso-zeaxanthin: The basic and clinical science underlying carotenoid-based nutritional interventions against ocular disease. Progress in Retinal and Eye Research, 50, 34-66.

[11] B. Bharathi, L. K., Singh, H. S., Shivashankar, S., Ganeshamurthy, A. N., \& Sureshkumar, P. (2014). Assay of nutritional composition and antioxidant activity of three dioecious Momordica Species of South East Asia. Proceedings of the National Academy of Sciences, India Section B: Biological Sciences, 84(1), 31-36.

[12] Boon, C. S., McClements, D. J., Weiss, J., \& Decker, E. A. (2010). Factors influencing the chemical stability of carotenoids in foods. Critical Reviews in Food Science and Nutrition, 50(6), 515- 532.

[13] Burke, D., Smidt, C., \& Vuong, L. (2005). Momordica cochinchinensis, Rosa roxburghii, wolfberry, and sea buckthorn-highly nutritional fruits supported by tradition and science. Current Topics in Nutraceutical Research, 3(4), 259.

[14] Charoonsri Chusak, Passavoot Chanbunyawat, Poorichaya Chumnumduang,

Praew Chantarasinlapin, Tanyawan Suantawee, Sirichai Adisakwattana. (2020). Effect of gac fruit (Momordica cochinchinensis) powder on in vitro starch digestibility, nutritional quality, textural and sensory characteristics of pasta. Volume 118. January 2020, 108856. https://doi.org/10.1016/j.lwt.2019.108856.

[15] Chen, D., Huang, C., \& Chen, Z. (2019). A review for the pharmacological effect of lycopene in central nervous system disorders. Biomedicine \& Pharmacotherapy, 111, 791-801.

[16] Chuyen, H. V., Nguyen, M. H., Roach, P. D., Golding, J. B., \& Parks, S. E. (2015). Gac fruit
(Momordica cochinchinensis Spreng.): A rich source of bioactive compounds and its potential

[17] health benefits. International Journal of Food Science \& Technology, 50(3),567-577.

[18] Crisp, P. (2012). Wild crop relatives: Genomic and breeding resources vegetables. Edited by $\mathrm{C}$. Kole. Heidelberg, Germany: Springer (2011), pp. 282, £135.00. ISBN 978-3- 642-20449-4. Experimental Agriculture, 48(2), 302.

[19] Dien, L. K. L., Minh, N. P., \& Dao, D. T. A. (2013). Investigation different pretreatment methods and ratio of carrier materials to maintain carotenoids in gac (Momordica cochinchinensis Spreng) powder in drying process. International Journal of Scientific \& Technology Research, 2(12), 360-371.

[20] Do, T. V. T., Fan, L., Suhartini, W., \& Girmatsion,

[21] M. (2019). Gac (Momordica cochinchinensis Spreng) fruit: A functional food and medicinal resource. Journal of Functional Foods, 62, 103512. doi:10.1016/j.jff.2019.103512

[22] Farhangi H, Ajilian M, Saeidi M, Khodaei GH. (2014). Medicinal fruits in Holy Quran. International Journal of Pediatrics, 2(3), 89-102.

[23] Fatmawati, I. (2019). The Halalan Toyyibah Concept In The Al-Qur'an Perspective And Its Application With Food Products In Indonesia. In Conference: 1st International Halal Conference \& Exhibition, 397-405.

[24] Herklots, G. A. C. (1973). Vegetables in southeast Asia.

[25] Honda, M., Watanabe, Y., Murakami, K., Takemura, R., Fukaya, T., Kanda, H., \& Goto, M. (2017). Thermal isomerization pre-treatment to improve lycopene extraction from tomato pulp. LWT, 86, 69-75.

[26] Huang, B., Ng, T., Fong, W., Wan, C., \& Yeung, H. (1999). Isolation of a trypsin inhibitor with deletion of $\mathrm{N}$-terminal pentapeptide from the seeds of Momordica cochinchinensis, the Chinese drug mubiezhi. The International Journal of Biochemistry \& Cell Biology, 31(6), 707-715.

Innun, A. (2013). I-SEEC

2012.

Proceeding-Science and Engineering, 1, 6.

[28] Ishida, B. K., Turner, C., Chapman, M. H., \& McKeon, T. A. (2004). Fatty acid and carotenoid composition of gac (Momordica cochinchinensis Spreng) fruit. Journal of Agricultural and Food Chemistry, 52(2), 274-279.

[29] Jamaludin, M. A., Ramli, M. A., \& Ab. Rahman, 
[30] S. (2011). Panduan makanan halal haram menurut perspektif al-Quran: Analisis terhadap isu-isu makanan semasa.

[31] Jung, K., Chin, Y.-W., Chung, Y. H., Park, Y. H., Yoo, H., Min, D. S., ... Kim, J. (2013a). Antigastritis and wound healing effects of Momordicae Semen extract and its active component. Immunopharmacology and Immunotoxicology, 35(1), 126-132.

[32] Liu, H.-R., Meng, L.-Y., Lin, Z.-Y., Shen, Y., Yu, Y.-Q., \& Zhu, Y.-Z. (2012). Cochinchina momordica seed extract induces apoptosis and cell cycle arrest in human gastric cancer cells via PARP and p53 signal pathways. Nutrition and Cancer, 64(7), 1070-1077.

[33] Mahdi, A. A. M. (2019). Effect of momordica cochinchinensis spreng, fruit on the proliferation and angiogenesis biomarkers of human retinal pigment epithelial cells under high glucose conditions. (Unpublished master's thesis). Universiti Putra Malaysia.

[34] Md Sidik, N. A. R. (2020). Rawatan enzimatik dan keadaan pengeringan yang berbeza terhadap serbuk pulpa gac (momordica cochinchinensis spreng). (Unpublished bachelor's dissertation). Universiti Sains Malaysia.

[35] Minh, N. P., \& Dao, D. T. A. (2013). Effect of different antioxidant ratios supplemented into mixture of Gac (Momordica cochinchinensis Spreng) seed membrane-carrier to total carotene; accelerated temperature to shelf-life of Gac powder. International Journal of Engineering Research \& Technology, 2, 1008-1015.

[36] Muhammad Ali, A. I. (2012). al-Nabatat fi AlQuran. Qaherah: Dar al-Islam.

[37] Muhammad, M. H. M. (2006). al-Thimar wa alA'syab al-Waridah fi al-Quran al-Karim wa alSunnah al-Nabawiyyah. Egpyt: Dar al-Nada.

[38] Mukherjee, A., Sarkar, N., \& Barik, A. (2014). Long-chain free fatty acids from Momordica cochinchinensis leaves as attractants to its insect pest, Aulacophora foveicollis Lucas (Coleoptera:

[39] Chrysomelidae). Journal of AsiaPacific Entomology, 17(3), 229-234.

[40] Muller-Maatsch, J., Sprenger, J., Hempel, J., Kreiser, F., Carle, R., \& Schweiggert, R. M. (2017). Carotenoids from gac fruit aril (Momordica cochinchinensis [Lour.] Spreng.) are more bioaccessible than those from carrot root and tomato fruit. Food Research International, 99, 928-935.
[41] Nur Khasanah. (2011). Kandungan buah-buahan dalam al-Quran: Buah tin (ficus carica L), zaitun (olea europea L), delima (punica granatum L), anggur (vitis vinivera L), dan kurma (phoenix dactylifera L) untuk kesehatan. Dosen Fakultas Tarbiyah IAIN Walisongo Semarang. Jurnal Phenomenon, 1(1), Julai 2011.

[42] Osman, M., Sulaiman, Z., Saleh, G., Rahman, M.

[43] S. A., Sin, M. A., Zainuddin, Hamidon, A. (2017). Gac fruit, a plant genetic resource with high potential. In Conference: 12th International Genetics Congress (MiGC12).

[44] Phan-Thi, H., \& Waché, Y. (2019). Behind the myth of the fruit of heaven, a critical review on gac (Momordica cochinchinensis Spreng.) contribution to nutrition. Current Medicinal Chemistry, 26.

[45] Qadah, A. (2009). Asrar al-Nabat. Dimashq: Dar al-Ghauthani li al-Dirasat al-Quran al-Karim.

[46] Rozhan Abu Dardak., (2015); "Transformation of Agricultural Sector in Malaysia Through Agricultural Policy", FFTC Agricultural

[47] Policy Platform(FFTC-AP), Taiwan

[48] https://ap.fftc.org.tw/article/818

[49] Shu, B., Yu, W., Zhao, Y., \& Liu, X. (2006). Study on microencapsulation of lycopene by spraydrying. Journal of Food Engineering, 76(4), 664-669.

[50] Sukhorum, W., Sampannang, A., Sripanidkulchai, B., \& Iamsaard, S. (2016). Momordica cochinchinensis (L.) Spreng. aril extract prevents adverse reproductive parameters of male rats induced with valproic acid. International Journal of Morphology, 34(3), 870-876.

[51] Syed Hassan, S. N. \& Ismail, M. Y. (2010). Buah zaitun: Keberkatan dan rahsia perubatan. In Conference: Seminar Ilmiah Kali-1 di Fakulti Pengajian Quran dan Sunnah, USIM.

[52] T.V.T. Do, et al. Journal of Functional Foods 62 (2019) 10351212

[53] T.V.T. Do, et al. Journal of Functional Foods 62 (2019) 10351213 from Gac aril (Momordica cochinchinensis Spreng L.). Vietnam. Journal of Science andTechnology, 48(1).

[54] T.V.T. Do, L. Fana, W. Suhartinia \& M. Girmatsionb. (2019). Gac (Momordica cochinchinensis Spreng) fruit: A functional food and medicinal resource. Journal of Functional Foods 62, 114. 
[55] USDA (2019). Taxon: Momordica cochinchinensis (Lour.) Spreng. U.S. National Plant Germplasm System. Agricultural Research Service, Germplasm Resource Information Network (GRINTaxonomy), https:/npgsweb.arsgrin.gov/gri nglobal/ taxonomydetail.aspx?24521 [Accessed on 22th of March].

[56] Wong, R. C., Fong, W., \& Ng, T. (2004). Multiple trypsin inhibitors from Momordica cochinchinensis seeds, the Chinese drug mubiezhi. Peptides, 25(2), 163-169.

[57] Xiao, C., Bao, G., \& Hu, S. (2009). Enhancement of immune responses to Newcastle disease vaccine by a supplement of extract of Momordica cochinchinensis (Lour.) Spreng. seeds. Poultry Science, 88(11), 2293-2297.

[58] [52] Xiao, C., Hu, S., \& Rajput, Z. I. (2007). Adjuvant effect of an extract from Cochinchina momordica seeds on the immune responses to ovalbumin in mice. Frontiers of Agriculture in China, 1(1), 90-95

[59] Yang, F., Zhang, M., Mujumdar, A. S., Zhong, Q., \& Wang, Z. (2018). Enhancing drying efficiency and product quality using advanced pretreatments and analytical tools-An overview. Drying Technology, 36(15), 1824-1838.

[60] Yu, J. S., Kim, J. H., Lee, S., Jung, K., Kim, K. H., \& Cho, J. Y. (2017). Src/Syk-targeted antiinflammatory actions of triterpenoidal saponins from Gac (Momordica cochinchinensis) seeds. The American Journal of Chinese Medicine, 45(03), 459-473.

[61] Zhao, L.-M., Han, L.-N., Ren, F.-Z., Chen, S.-H., Liu, L.-H., Wang, M.-X., ... Shan, B.-E. (2012). An ester extract of Cochinchina momordica seeds induces differentiation of melanoma B16 F1 cells

[62] via MAPKs signaling. Asian Pacific Journal of Cancer Prevention, 13(8), 3795-3802.

[63] Zheng, L., Zhang, Y.-M., Zhan, Y.-Z., \& Liu, C.X. (2014). Momordica cochinchinensis seed extracts suppress migration and invasion of human breast cancer ZR-75-30 cells via downregulating MMP-2 and MMP-9. Asian Pacific Journal of Cancer Prevention, 15(3),1105-1110.

[64] Zulkepli, M. K. A. (2016). Buah-buahan dalam alQuran menerusi aspek bahasa Arab. Jurnal Sultan Alauddin Sulaiman Shah, 3(2). Bangi: Universiti Kebangsaan Malaysia. 